\title{
Vaccine hesitancy? No, government failure
}

The media, both social and otherwise, have been full of the irresponsible rantings of a well-known health professional against the COVID-19 vaccination in the past couple of days. And rightly so. But I believe that the reasons for reduction in vaccine uptake in the past weeks have little to do with hard anti-vaxx sentiment and far more to do with lack of information and access. An article in Guardian Online ${ }^{[1]}$ by Nasrine Malik resonated. Titled 'Vaccine hesitancy is a symptom of people's broken relationship with the state', the writer told of her experiences in her home country of Sudan. When the first batch of donated vaccines were sent to Sudan earlier this year, members of her family rejected them because of a rumour that the vaccines were unsafe because they had not been correctly stored. A new batch of vaccines was regarded as a 'reject' because it had been donated by Western countries rather than being thrown away. As Malik said, 'State failure breeds paranoia. And when trust in government breaks down, people turn to personal vigilance.'

We are living in a country where corruption is endemic. Our previous minister of health resigned just before being fired over the inappropriate awarding of a tender that was supposedly to provide information around the COVID-19 pandemic and vaccines, but was rather used for personal gain. Our first round of vaccine registrations and appointments aimed at those aged over 60 was pretty much a failure, leaving many of the elderly and vulnerable behind simply because the technology employed was inappropriate. As a result the initial roll-out was glacial, which in itself will have fuelled vaccine hesitancy. If no-one around you is being vaccinated, you won't be either. As vaccination opened up to younger age groups, uptake initially improved, but has recently significantly fallen off, with vaccine centres looking for people to vaccinate and doses unused. And now Joe Phaahla, our current minister of health, is worried about slow uptake of COVID-19 vaccines, citing misinformation as the reason and conceding that 'they should be doing more to build public confidence. ${ }^{[2]}$ While it is quite true that there is a proportion of people who are vehemently anti-vaccine (and probably also believe the Earth is flat), the majority of 'hesitancy' in the country is highly unlikely to be anything to do with the rantings of a cardiac surgeon.

It is only very recently that there has been a serious effort to get vaccines to the elderly in rural areas. All through the efforts of an NPO, led by Jane Simmons ${ }^{[3]}$ who, after much persuasion, managed to get the Department of Health on board to target the elderly in grant queues, something that should have been done right from the start. In Limpopo, health authorities have taken things into their own hands and implemented what they knew would work for the province. ${ }^{[4]}$ Vaccines were delivered through existing service delivery platforms, providing more than 3000 points of contact. When the health worker vaccination trial started, one hospital per district was used as the central facility, the 'hub', and district hospitals were used as the 'spokes'. This worked and was massively scaled up when vaccinations started for the general population. The health department enlisted the help of influencers and religious and community leaders, as well as community health workers who actively registered people. The vaccination team went to the offices of the tribal councils, community halls and malls and set up a drivethrough vaccination station. It worked. Limpopo has the highest per capita vaccination rate in the country.

We are now well into a serious third wave of the virus, with further hospitalisations and deaths, most of which could have been averted through vaccination. We have also suffered the imposition of a State of Disaster and the subsequent lack of parliamentary oversight and transparency in our governance structure since March last year. We have endured draconian restrictions and lockdowns, which have done nothing to prevent infection and deaths. Our current lockdown regulations did nothing to the current trajectory of the virus, which is simply following a natural course and will subside again once a substantial portion of the population has been infected. People have lost their livelihoods, their homes, members of their families and, I am quite sure, trust in government over the past 15 months. And there is still no serious effort to inform and educate the public about the virus, the current high transmissibility of the circulating variants, and the effectiveness of vaccines in preventing severe illness and deaths. There will be more waves of this virus. Without massively increasing the numbers of people vaccinated, there will be more hospitalisations and deaths. We need to vaccinate as many vulnerable people as possible now. The lack of uptake in vaccine centres is not due to the tirades of a few radical antivaxxers. It is due to a systematic lack of engagement by a government who have lost track of the needs of our population, solely focused on their own narrow agenda. We need information, widely disseminated, in as many forms as possible, right now.

\section{Bridget Farham \\ Editor \\ ugqirha@iafrica.com}

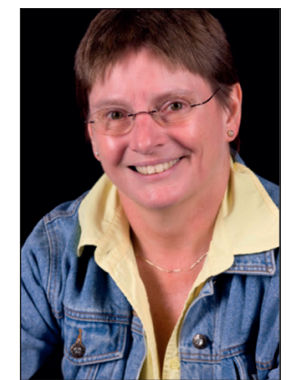

Malik N. Vaccine hesitancy is a symptom of people's broken relationship with the state. Guardian, 15 August 2021. https://www.theguardian.com/commentisfree/2021/aug/15/vaccine-hesitancy-brokenrelationship-state-conspiracy-theorists (accessed 16 August 2021).

EWN. Health Minister Phaalha worried about slow uptake of COVID vaccines. https://ewn.co.za/2021/08/16 health-minister-phaahla-worried-about-slow-uptake-of-covid-vaccines (accessed 16 August 2021).

Ellis E. Getting to the gogos: South Africass vaccination story of hope and trust. Daily Maverick, 15 August 2021. https://www.dailymaverick.co.za/article/2021-08-15-getting-to-the-gogos-south-africasvaccination-story-of-hope-and-trust/ (accessed 16 August 2021).

4. Ellis E. Bespoke(s) roll-out: Limpopo is winning the vaccine race with baby steps. Maverick Citizen, 13 August 2021. https:/www dailymaverick co za/article/2021-08-13-bespokes-roll-out-limpopo-iswinning-the-vaccine-race-with-baby-steps/ (accessed 16 August 2021). 